\title{
SPHAEROTHECA FULIGINEA (POWDERY MILDEW) PARASITIC ON MACROTYLOMA UNIFLORUM (GAHAT): A FUNGUS NEW TO NEPALESE MYCOFLORA
}

\author{
MAHESH KUMAR ADHIKARI \\ GPO Box no. 21758, Kathmandu, Nepal \\ mkg_adh@wlink.com.np
}

\section{ABSTRACT}

The powdery mildew (a fungus) Sphaerotheca fuliginea (Sch.: Fr.) Poll., parasitic on Macrotyloma uniflorum (Lam.) Verdc (Gahat) is recorded as new addition to Nepalese mycoflora. The description and distribution to the species is provided herewith.

Keywords: Erysiphales, Sphaerotheca, Macrotyloma, Nepal

\section{INTRODUCTION}

Till now only few authors have contributed their findings on powdery mildews from various places of Nepal (Adhikari, 2009). Notably they are Adhikari (2009, 2012), Adhikari et al. (1997, 2006), Bhatta (1966), Khadka \& Shah (1967), Khadka et al. (1968), Joshi (1977), Lama (1976,1977), Manandhar \& Shah, (1975), Manandhar \& Shah (1975), Pandey \& Adhikari (2005), Parajuli et al. (1999), Pawsey (1989), Singh (1968) and Singh \& Nisha (1976). The check reference list of the previous reports can be seen in Fungi of Nepal, Part 2: Mastigomycotina, Zygomycotina and Ascomycotina. (Adhikari \& Manandhar, 1997) and Fungi of Nepal, Part 3: Deuteromycotina (Adhikari \& Manandhar, 2001).

Previously Sphaerotheca pannosa (Waller). Lev. on Rosa indica Linn. and Rosa sp., Putalisadak, Kathmandu (Singh,1968) and Sphaerothca sp., on Rose, Kathmandu (Bhatt, 1966) have been reported from Nepal.

The present fungus is not gathered and described from Nepal. The photographs of the fungus (with host, conidiophores, conidiospores and cleistotheciua) is provided below.

\section{Description of the fungus}

Sphaerotheca fuliginea (Sch.: Fr.) Poll. In Atti. Ist. Bot. Uni. Pavia ; Braun, A monograph of the Erysiphales (powdery mildews). Nova Hedwigia. 89: 134, 1987.

Description - Colonies amphigenous, mostly on upper surface of leaf, effecting pods also, effused to irregular patches, thin, powdery, sometimes covering whole surface, white, cottony, infected portions turning grayish brown to black. Hyphae up to $15 \times 6 \mu \mathrm{m}$ broad, hyaline, thin walled, cylindrical, straight to curved, branched, septate, Haustoria not seen. Conidiophores up to 15 - $80 \times 2-17.4 \mu \mathrm{m}$ straight, cylindrical, rounded at tip, with 2 - 3 conidiogenous cells, upper cells up to $40 \times 15-18 \mu \mathrm{m}$, basal cells up to $50 \times 17.4 \mu \mathrm{m}$, thin walled, hyaline, foot cells, cylindrical, sometimes curved, hyaline, thin wall. Conidiospores 31. 9 - 50 X 8.7 - 20.3 $\mu \mathrm{m}$, hyaline, thin walled, with 1 guttulate, ovoid, doliform to ellipsoid to cylindric, barrel shaped 
also, germinating tubes thin walled, up to $45 \mu \mathrm{m}$ long, hyaline. Cleistothecia blackish brown, ovoid, scattered, $87-100 \mu \mathrm{m}$, cells upto $14.5 \times 8.7 \mu \mathrm{m}$, globose to irregular, elongated. Appendages, septate, hyaline, up to 12 , few to numerous, breaking readily, mycelloid, curved, up to $205 \mu \mathrm{m}$, long, not branched, simple, Ascus $70-75 \mu \mathrm{m}$, one, oval, hyaline, 6 spored. Ascospore $20-32 \times 14-23 \mu \mathrm{m}$, oval to ellipsoid, smooth, brownish.

Specimen examined - Parasitic on Macrotyloma uniflorum (Lam.) Verdc. (Fabaceae), [Previously erroneously called Dolichus biflorus auct non Linn.; Dolichus uniflora Linn.], Bhanimandal, Lalitpur, no.2069.7.18, (2012,11.3), MK Adhikari.

Distribution - Australia,Europe, Asia, USSR and North America.

\section{Comments}

Macrotyloma uniflorum (Lam.) Verdc. is known as Gahat in Nepali and Horse Gram in English. The other names are Kulath, Kulthi (Hindi); Kollu (Tamil), Ulavalu (Telugu) and Galath.

Spheartheca fuliginea (Schl. Fr.) Poll. has been reported from Australia and New Zealand (Anon, 1965) on Macrotyloma uniflorum (http://www.tropicalforages.info/key/Forages/Media/ $\mathrm{Html} /$ Macrotyloma_uniflorum.htm). Braun's report (1987) of Sphaerotheca fuliginea has amphigenous mycelium, conidia in chains, ellipsoid - ovoid - doliform conidia, 24 - 35 x 15 - $19 \mu \mathrm{m}$, conidiophores straight, foot cells $45-95 \times 9.5-12 \mu \mathrm{m}$ but it differs being reported parasitic on Veronica species only. The foot cell of the present species has curved cylindrical hyphae with larger ovoid to barrel shaped conidiospores. Erysiphe glycines Tai has ovoid, ellipsoid - dolliform to barrel shaped conidiospores and produces many asci. It has been reported parasitic on (Glycine, Phaseolus) from Asia and N. America.

The powdery mildew (Leveillula taurica (Lév.) G. Arnaud,) on horse gram [Macrotyloma uniflorum (Lam.) Verdc] was reported from southern Karnataka, India (Naik, 2000). It differs from the present specimen in the shape and sizes of conidiophres and conidiospores.

Braun's key to powdery mildews parasitic on Fabaceae species is based entirely on cleistothecial structures and its appendages. In Fabaceae many powdery mildews of the genera viz.: Brasiliomyces, Erysiphe (E. puerariae, E, thermopsidis, E. viciae-unijugae, E. pisi, E. caulicola, E. cercidis, E. glycine, E. deserticola) Phyllactinia, Pleochaeta, Uncinula, Oidiopsis, Leveillula taurica, and Microsphaera (M. acaciae, M. astragali, M. cladrastidis, $M$. palezewskii, M. subtrichotoma, M. ludens, M. diffusa, M. Iongissima, M. pseudoacaciiae, $M$. robiniae, $M$. ravenelii, $M$. rayssiae, $M$. astragali, $M$. baeumleri, $M$. trifolii, $M$. hedysari, $M$. alhagi, M. guarinonii, M. swainsoniae, M. coluteae and $M$. chaurdii) are reported. None of these species match with the present species.

It's the record of new host from Nepal.

\section{REFERENCES}

ADHIKARI, M K (2009) Researches on the Nepalese mycoflora: revised account on the history of mycological explorations. ADHIKARI, K.S. Kathmandu, Nepal; 92 pp.

ADHIKARI, M K (2012) Erysiphe cichoracearum DC.: The powdery mildew (Erysiphales) from Nepal. Bull. Dept. PI. Res. 34:18-21. 
ADHIKARI, M K (2012) The Oidium species: powdery mildews (Erysiphales) from Nepal. Bull. Dept. PI. Res. $34: 26-30$.

ADHIKARI, M K; MANANDHAR, V (1997) Fungi of Nepal, Part 2: Mastigomycotina, Zygomycotina and Ascomycotina. Bull. Dept. PI. Res. 16: 60.

ADHIKARI, M K; MANANDHAR, V (2001) Fungi of Nepal, Part 3: Deuteromycotina Bull. Dept. Pl. Res. 17: 38 .

ADHIKARI, M K, MANANDHAR, V; JOSHI, L; KURMI, P P (2006) Die back of Dalbergia sissoo in western tarai belt of Nepal. Bull. Dept. PI. Res. 27: 30-38.

ANON, H (1965) New Plant diseases. Agric. Gaz, N.S.W. 76: 38-41

BHATT, D D (1966) Preliminary list of plant diseases recorded in Kathmandu valley. Jour. Sc. 2: 13-20.

BRAUN, U (1987) A monograph of the Erysiphales (powerdry mildews). Nova Hedwigia, 89, .J. Cramer, Stuttgart, Germany; pp 200.

Joshi, A R (1977) A contribution to parasitic fungi of Nepal. Journal of Natural History Museum 1: 221-226.

KHADKA, B B; SHAH, SM (1967) Preliminary list of plant diseases recorded in Nepal. Nep. Jour. Agri. 2: $47-76$.

KHADKA, B B; SHAH, S M; LAWAT, K (1968) Plant diseases in Nepal: a supplementary list. Tech. Doc. 66 FAO PI. Prot. Comm. South-East Asia and Pacific Region, Bangkok, Thailand.

LAMA, T K (1976) Some parasitic fungi from Pokhara (W. Nepal). Jour. Sc. 6: 49-52.

LAMA, T K (1977) Some parasitic fungi from Pokhara. Journal of Natural History Museum 1: 63-66.

MANANDHAR, K L; SHAH, S M (1975) List of plant diseases in Nepal.:second supplement. Tech. Doc. 97. FAO PI. Prot. Comm. South - East Asia and Pacific region, Bangkok, Thailand.

NAIK, R G (2000) Chemical control of powdery mildew in horsegram (Macrotyloma uniflorum Lam.) Verdec. Journal Legum Research 23(4): 262-264

PANDEY, B. AND ADHIKARI, M. K. (2005) Odium citri: the Citrus disease in Nepal. Bull. Dept. Pl. Res. 26: $6-7$

PARAJULI, A V; BHATTA, B; ADHIKARI, M K; TULADHAR, J; THAPA, H B (1999) Causal agents responsible for the die-back of Dalbergia sissoo in Nepal's eastern Terai. Banko Janakari 9(1): 7-14.

PAWSEY, R G (1989) A check reference list of plant pathogens in Nepal. FRIC Occasional paper. no. 1/89, Kathmandu, Nepal.

SINGH, S C (1968) Some parasitic fungi collected from Kathmandu valley (Nepal). Ind. Phytopath. 21: 23-30.

SINGH, S C; NISHA (1976) A contribution to the parasitic mycoflora of Nepal. Ibid. 6: 11-14.

Web page - http://www.tropicalforages.info/key/Forages/Media/Html/Macrotyloma_uniflorum.htm). 


\section{PHOTOGRAPH OF THE FUNGUS}

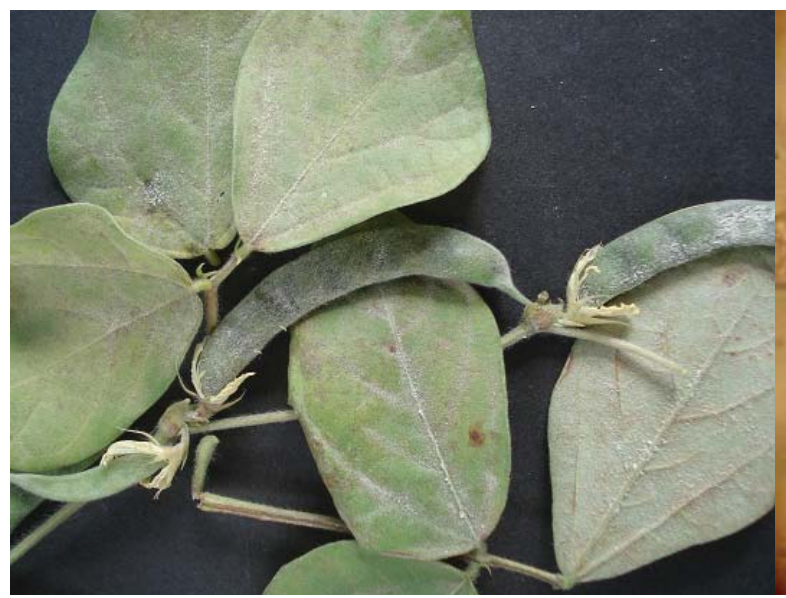

Macrotyloma infected with powdery mildew

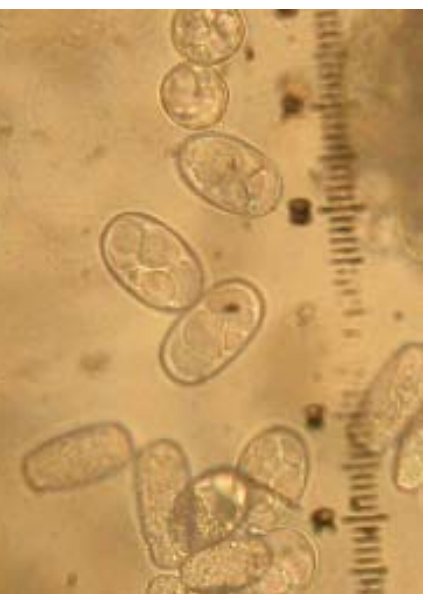

Conidiospores (10 x 40)

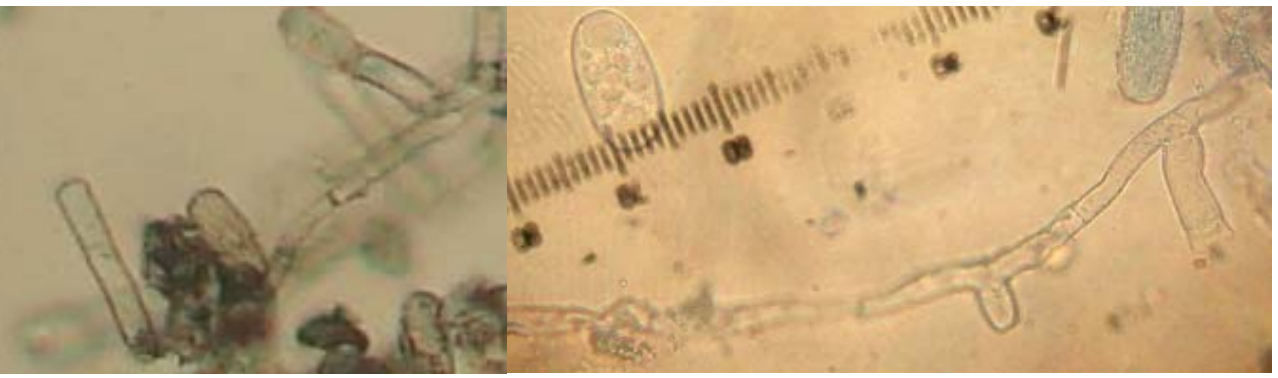

(Microscopic measurement 10 x 40) Hyphae, conidiophores and conidia

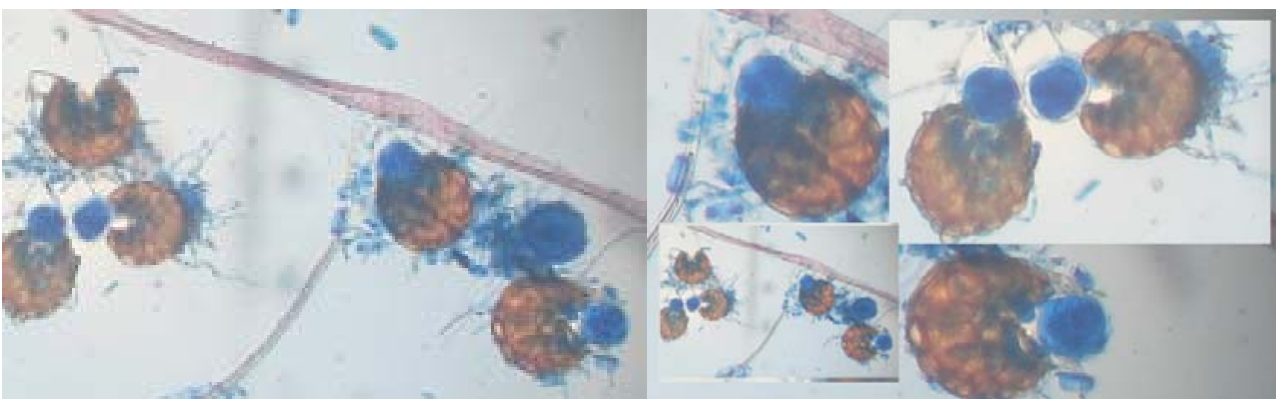

Cleistothecium $(10 \times 10)$ 